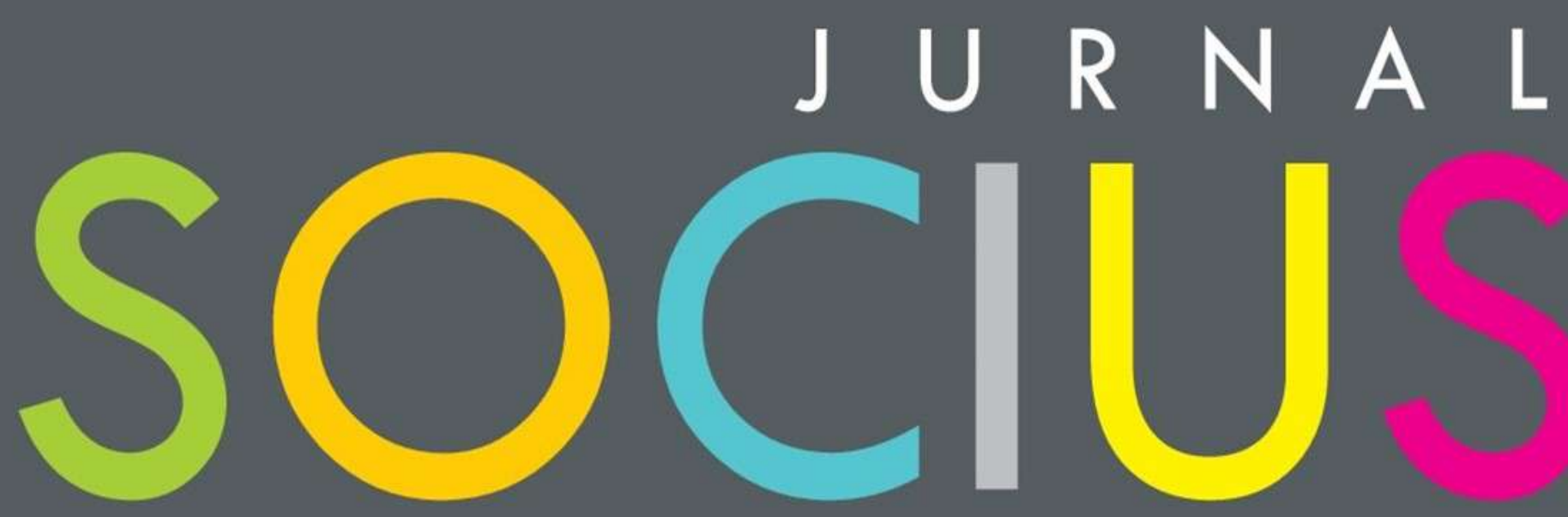

Journal of Sociology Research and Education

DITERBITKAN OLEH :

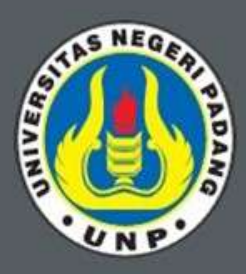

$\angle A B O R$

JURUSAN SOSIOLOGI FAKULTAS ILMU SOSIAL UNIVERSITAS NEGERI PADANG

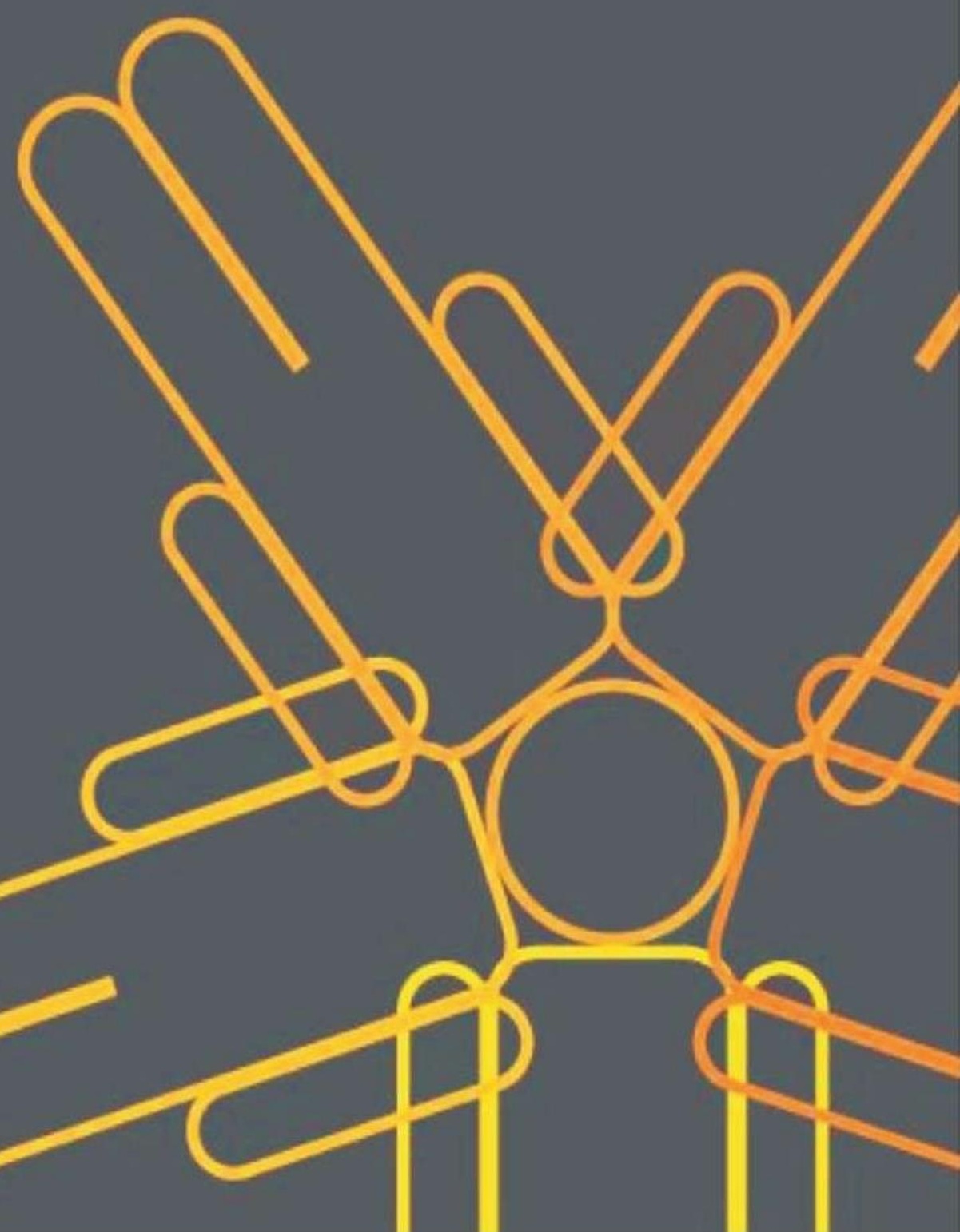




\section{SOCIUS}

Vol. 7, No. 2, Th. 2020

ISSN : 2356-4180 (cetak)

2442-8663 (online)

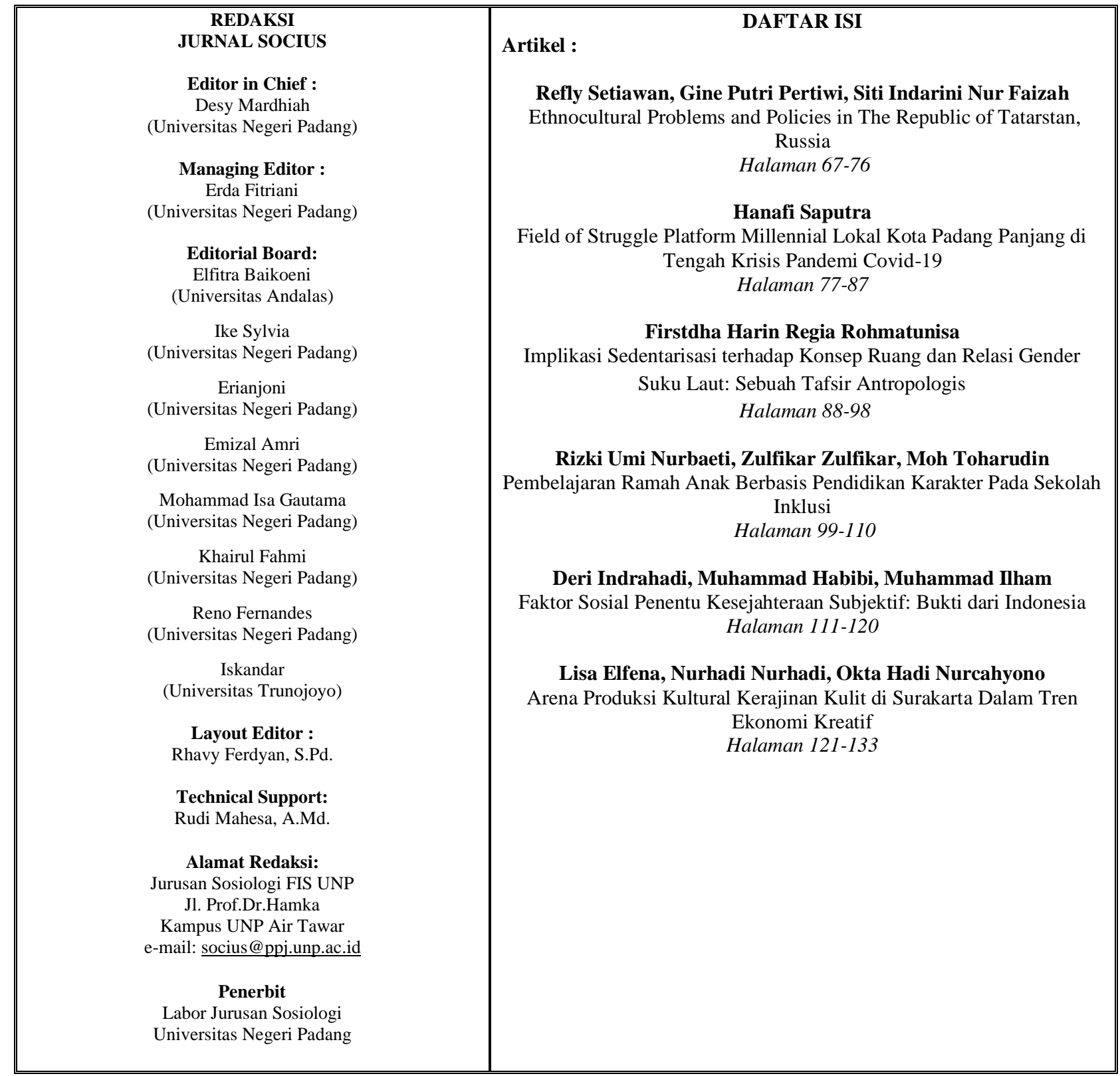




\title{
Implikasi Sedentarisasi terhadap Konsep Ruang dan Relasi Gender Suku Laut: Sebuah Tafsir Antropologis
}

\author{
Firshda Harin Regia Rohmatunnisa \\ Universitas Indonesia \\ Email: firstdha.gia@gmail.com
}

\begin{abstract}
Abstrak
Telah lama para peneliti tertarik untuk mengkaji budaya maritim masyarakat seafaring atau juga yang biasa disebut sebagai sea nomad, seperti Suku Laut di Kepulauan Riau. Namun sejak tahun 1990-an, kelompok masyarakat ini telah mengalami perubahan yang diawali dengan terjadinya sedentarisasi. Mereka yang biasa hidup mengarungi lautan dengan sampan beratap kajang, kini telah memiliki rumah di tepian sebagai tempat untuk menetap. Artikel ini membahas mengenai implikasi dari sedentarisasi terhadap spasialitas Suku Laut, serta dinamika relasi gender yang hadir karena perubahan tersebut. Melalui studi pustaka, diketahui bahwa sedentarisasi membawa dinamika terhadap konsep ruang dan relasi gender di Suku Laut. Dinamika tersebut dilihat melalui kehadiran rumah sebagai ruang antara yang menjembatani antara seascape dan landscape. Melalui kerangka gendered space, rumah menjadi lokus terjadinya artikulasi gender yang mendorong Suku Laut untuk mendefinisikan ulang relasi serta peranan perempuan di dalam dan di luar komunitas. Kajian ini memberi gambaran mengenai perubahan dan problematika yang berkaitan dengan ruang dan gender Suku Laut di Kepulauan Riau.
\end{abstract}

\section{Kata Kunci: Gender, Ruang, Sedentarisasi, Suku Laut}

\begin{abstract}
Researchers have long been interested in studying the maritime culture of seafaring people or also commonly referred to as sea nomads, such as the Suku Laut in the Riau Archipelago. But since the 1990s, this community group has experienced a change that begins with the occurrence of sedentarisation. Those who used to live across the ocean with kajang, now have a house on the edge as a place to stay. This article discusses the implications of sedentarization of Suku Laut's spaciality, as well as the dynamics of gender relations that are present because of these changes. Through literature studies, it appears that sedentarisation brings dynamics to sense of space and even gender relations in Suku Laut. This dynamic is seen through the presence of the house as an intermediate space that bridges between seascape and landscape. Through the framework of 'gendered space', the house becomes the locus for the implementation of gender articulation that encourages the Suku Laut to redefine the relations and roles of women inside and outside the community. This study provides an overview of changes and problems related to the space and gender of the Sea Tribe in the Riau Archipelago.
\end{abstract}

Kata Kunci: Gender, Sedentarization, Suku laut, Space

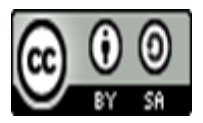

Received: August 8, 2020

Revised: November 21, 2020

Available Online: December 21, 2020

Jurnal Socius: Journal of Sociology Research and Education Vol. 7, No.2, Th. 2020 


\section{Pendahuluan}

Suku Laut merupakan masyarakat yang dikenal biasa hidup di atas sampan dan beratapkan kajang. Karena pola hidup yang mengembara mengikuti pola sumberdaya laut, mereka biasa disebut sebagai seafaring, sea gipsies, sea nomad, boat - people/ boatdwelling people (Lenhart, 1997). Keberadaannya dapat ditemukan di perairan-perairan di Kepulauan Riau, di pantai selatan Semenanjung Johor, di sebelah timur pantai Sumatera, di Kepulauan Bangka Belitung, dan juga di sekitar pantai utara Singapura (Chou, 2016).

Mereka dipimpin oleh seorang pemimpin (big man) yang ditunjuk oleh sekumpulan kerabat dalam kelompok sosial yang relatif kecil berupa keluarga batih. Dalam relasinya antar sesama, mereka saling menghormati, baik itu dalam internal maupun eksternal suku (Lenhart, 2003). Dalam konteks relasi gender di masyarakat Suku Laut, tidak ada pembeda yang jelas terutama dalam hal pembagian kerja (Chou, 2005). Tidak ada ketimpangan atau dominasi dari salah satu pihak terhadap pihak lainnya. Hal itu kerena mereka lebih banyak hidup di sampan, dan menuntut semuanya untuk memiliki keterampilan sebagai pelaut. Sehingga pembagian peran hampir tidak ada bedanya, termasuk dalam mengasuh anak dan memberi pendidikan untuk menjadi seorang nelayan dan pelaut yang handal (Prawirosusanto, 2014).

Sejarah menceritakan bahwa Orang Laut adalah kelompok masyarakat yang handal di ranah maritim, oleh karena itu Suku Laut pada zamannya sangat dekat dengan Kesultanan Melayu. Bahkan Kerajaan Sriwijaya mengandalkan Orang Laut sehingga menjadi kerajaan maritim terbesar di Nusantara (Wee \& Chou, 1997). Akan tetapi dari sudut pandang negara pasca-kolonial, Orang Laut ditempatkan pada posisi yang marjinal. Mereka justru dikategorikan sebagai suku terasing, yang tidak mengenal peradaban dan modernitas. Mereka dianggap berbahaya, tertinggal, bodoh, tidak beragama (menganut kepercayaan lokal), bahkan dianggap tidak sesuai dengan nilai-nilai Pancasila. (Prawirosusanto, 2015). Oleh sebab itu Orang Laut menjadi sasaran proyek pembangunan pemerintah Indonesia, terutama ketika Kepulauan Riau dijadikan sebagai bagian dari suatu proyek pembangunan multinasional dalam bentuk kerjasama SIJORI (Singapura - Johor - Riau). Salah satu ambisi pemerintah dalam memodernkan Suku Laut adalah dengan membatasi akses mereka terhadap laut, dan membuatkan pemukiman untuk mereka. Suku Laut juga menjadi terikat dengan regulasi yang mengatur mobilitas mereka, terutama ketika mereka harus melintasi batas-batas Negara (Chou, 2016).

Tentunya dengan memukimkan Orang Laut di pulau-pulau tertentu seperti Pulau Bertam dan Belakang Padang, telah membawa berbagai dampak terhadap kehidupan sosial-budaya Orang Laut. Hal itu memaksa Orang Laut untuk menjalani pola hidup yang berbeda dengan yang dulu biasa mereka jalani, membawa diri mereka kepada kesadaran baru "kesadaran sebagai Orang Laut yang mendarat" (Prawirosusanto, 2015). Atas nama pembangunan, Negara beserta agen-agennya mencoba 'memajukan' Suku Laut yang di mata mereka adalah orangorang yang terbelakang dan tidak berpendidikan. Hal itu salah satunya dilakukan melalui kerja sama bersama orang-orang muslim Melayu, yang menerapkan adat melayu sebagai tolak ukur keberadaban. Beberapa poin itu, diantaranya: (1) membangun tempat ibadah, (2) ibadah sholat lima waktu, (3) kepemilikan properti berdasarkan gender, (4) dan pembagian kerja yang dibedakan berdasarkan gender (Benjamin \& Chou, 2006). Tentunya hal ini membawa perubahan dalam kehidupan sosial-budaya Orang Laut.

Telah banyak sebelumnya yang menyoroti perubahan sosial budaya Suku Laut di Kepulauan Riau, atau pun komunitas serupa seperti Orang Sama Bajau yang berada di wilayah lain di Indonesia. Perubahan tersebut seringkali dikaitkan dengan fenomena globalisasi dan modernisasi, melalui upaya sedentarisasi yang didorong oleh pemerintah. Dalam hal ini literatur sebelumnya menampilkan corak yang sama mengenai bagaimana Suku Laut di Kepulauan Riau tereksklusi oleh agenda pembangunan. Mereka dipaksa untuk tinggal dan

Jurnal Socius: Journal of Sociology Research and Education Vol. 7, No.2, Th. 2020 
mengadopsi gaya hidup orang darat yang diasumsikan sangat berbeda dengan gaya hidup mengapung di atas sampan bekajang yang menjadi gaya hidup mereka sebelumnya. Oleh sebab itu berbagai konsekuensi mengenai ruang hidup, teritorial, mode produksi, dan identitas menjadi isu yang paling banyak dibahas. Dari sini saya tertarik untuk bergabung dalam membahas isu-isu mengenai konsekuensi dari proses sedentarisasi dengan menyoroti implikasinya terhadap spasialitas, yang menunjukan dinamika akan dua kesadaran perihal ruang (seascape dan landscape) dan tempat, serta peranannya dalam mengartikulasikan relasi gender di komunitas Suku Laut.

Mengapa ruang dan gender? Pertama, saya melihat bahwa perspektif ruang bagi Suku Laut menjadi hal yang sangat signifikan. Perdebatan mengenai seascape sebagai ruang hidup ataupun sebagai tempat, tampaknya masih belum banyak dikaji. Karena laut seringkali dipandang sebagai wilayah yang tidak terjamah, tidak dapat ditinggali, dan membutuhkan daya survival yang tinggi (Chou, 2016). Laut sebagai place juga masih diperdebatkan, karena istilah tersebut erat kaitannya dengan metafora daratan yang 'mengakar' dan 'membumi', yang sama sekali tidak merepresentasikan seascape (Lowe, 2003). Oleh karena itu, fenomena sendentarisasi yang terjadi pada Suku Laut setidaknya memantik diskusi mengenai perubahan dan perdebatan mengenai realitas laut dan darat dalam kehidupan Suku Laut.

Kedua, melalui narasi tentang seascape dan landscape dapat dipahami mengenai relasi gender yang ada di Suku Laut. Penelitian sebelumnya belum banyak yang menaruh perhatian pada relasi gender di Suku Laut, hal itu disebabkan oleh asumsi sebagian besar peneliti yang mengkaji Suku Laut atau masyarakat seafaring lainnya dalam melihat relasi gender di Suku Laut lebih bersifat egaliter, komplimenter (Lenhart, 2003), atau bahkan non-gendered (Chou, 2005). Asumsi tersebut didasarkan pada tidak adanya pembeda yang jelas dalam hal akses terhadap sumber daya laut, karena baik laki-laki ataupun perempuan Suku Laut mereka samasama pergi melaut. Konsekuensinya, relasi gender Suku Laut seringkali diabaikan karena dianggap tidak relevan dalam membahas marjinalitas Suku Laut. Selain itu, pandangan mengenai gender dalam kajian sebelumnya masih sangat fungsionalis dan dianggap sebagai suatu produk kebudayaan yang statis. Dalam hal ini saya sepakat dengan pandangan Tsing (1990) bahwa gender adalah proses, bukan produk kultural. Gender selalu diartikulasikan dalam berbagai level yang ada di masyarakat, dan bahkan dapat terjadi kontradiksi pada apa yang menjadi ideal di suatu kebudayaan dengan praktik sehari-hari.

\section{Metode Penelitian}

Artikel ini merupakan hasil dari studi kepustakaan dengan tujuan mendapatkan suatu gambaran utuh mengenai dinamika kehidupan Suku Laut beserta permasalahan yang dihadapi oleh komunitas ini dalam kerangka spasialitas dan gendered space. Kajian pustaka dilakukan dengan menggunakan teknik dokumentasi sebagai metode pengumpulan data. Yaitu dengan mengumpulkan dan meninjau tulisan-tulisan terdahulu yang membahas isu-isu suku laut di Kepulauan Riau, dan juga komunitas serupa yang ada di wilayah lain seperti Orang Bajau di Sulawesi. Kemudian analisis konten dilakukan untuk mengidentifikasi permasalahan yang banyak dibahas yang berkaitan dengan kebudayaan dan spasialitas Suku Laut, serta mencari celah dalam perdebatan yang belum begitu banyak didalami. Selain itu dalam tulisan terdahulu juga terdapat banyak data dan deskripsi yang dapat ditelaah secara lebih mendalam, dan dibingkai dalam satu perspektif yang agak lain. Dalam hal ini, perspektif gender menjadi agak berbeda dari sekedar deskripsi mengenai kebudayaan laki-laki dan perempuan dalam beberapa literatur Suku Laut yang selama ini mendeskripsikannya secara implisit. Oleh karena itu hasil telaah ini, setidaknya menyumbang terhadap kajian Suku Laut, dengan secara khusus mengangkat gender melalui kerangka gendered space. 
Dari hasil studi pustaka, salah satu isu yang penting dalam melihat kehidupan Suku Laut adalah perihal sedentarisasi yang dianggap telah membawa berbagai perubahan dalam setiap unsur kehidupan Suku Laut. Perubahan-perubahan tersebut salah satunya mencakup perspektif mengenai ruang dan relasi gender. Oleh karena itu pertanyaan yang harus dijawab dalam artikel ini adalah mengenai implikasi sedentarisasi terhadap perspektif ruang dan relasi gender suku laut. Untuk itu saya membagi artikel ini kedalam beberapa bagian. Bagian pertama dibahas mengenai sedentarisasi serta berbagai perdebatan peneliti terdahulu dalam melihat faktor pendorong masyarakat nomaden untuk mulai tinggal menetap. Kemudian konsekuensinya terhadap perspektif ruang Suku Laut, serta perdebatan peneliti sebelumnya mengenai orientasi ruang antara laut dan darat akan dibahas di bagian kedua. Terakhir, adalah implikasi dari sedentarisasi terhadap relasi dan pembagian kerja berdasarkan gender di suku laut yang kini telah tinggal di rumah.

\section{Hasil dan Pembahasan}

\section{Sedentarisasi Suku Laut: 'Dua Sistem' yang mendorong komunitas nomaden agar bermukim}

Dalam melihat proses sedentarisasi, para peneliti sebelumnya seringkali mengaitkannya pada proses pembentukan dan kepengaturan negara terhadap kelompok masyarakat tertentu (Kent, 1995). Kelompok masyarakat yang mengalami proses 'penertiban' atau sedentarisasi itu merupakan masyarakat yang notabene menjalani pola hidup nomaden, tak terkecuali Suku Laut. Pola hidup Orang laut yang nomaden, mereka seringkali dilihat sebagai masyarakat primitif yang gaya hidupnya tidak sesuai atau menyimpang dari standar yang ditetapkan negara mengenai masyakat. Selain menyimpang, mereka dipandang berbahaya dan tidak dapat dikontrol. Sehingga negara dengan berbagai aparatusnya berkepentingan untuk melakukan pendisiplinan melalui berbagai mekanisme seperti mencanangkan program pemukiman penduduk, mencatat individu sebagai warga negara, dan memberlakukan pajak.

Pada kasus Suku Laut, mereka merupakan masyarakat yang dikenal biasa hidup di sampan (kajang). Pola hidup mereka yang mengembara mengikuti pola sumberdaya laut, mereka biasa disebut sebagai sea nomad atau juga sea gypsies (Lenhart, 1997). Akan tetapi, karena pola hidup itu mereka dianggap berbahaya, tertinggal, bodoh, tidak beragama (menganut kepercayaan lokal), bahkan dianggap tidak sesuai dengan nilai-nilai Pancasila (Prawirosusanto, 2015). Oleh pemerintah Indonesia, mereka dimasukkan ke dalam kategori masyarakat terasing dan tertinggal yang harus ditingkatkan taraf hidupnya. Oleh karena itu di tahun 1985, Pemerintah secara khusus mencanangkan program Pembinaan Kesejahteraan Masyarakat Terasing (PKMT) di Batam dan sekitarnya(Lenhart \& Casimir, 2001). Berbagai tahapan pembangunan (1985 - 1992) dilakukan, dimulai dari penentuan lokasi settlement hingga pembangunan berbagai infrastruktur (rumah, MCK, masjid, dan sekolah) lengkap dengan program pemberdayaan.

Apakah program itu berhasil atau tidak? Tampaknya hingga saat ini tidak begitu menjadi sesuatu yang dipermasalahkan oleh pemerintahan Kota Batam atau bahkan Kepulauan Riau. Adapun yang dianggap menjadi masalah adalah kesulitan dalam melakukan pencatatan penduduk untuk Suku Laut (Prawirosusanto, 2014), hal itu karena kehidupan nomaden yang belum sepenuhnya bisa mereka tinggalkan meskipun sudah memiliki rumah. Hal ini disebabkan pada musim tertentu, Orang Laut masih berpergian hingga berbulan-bulan untuk mencari ikan, kemudian ada juga beberapa anggota keluarga yang tidak betah di rumah dan memilih kembali hidup di sampan sehingga masih sulit untuk dicatat keberadaannya secara administrasi. Setidaknya mengkaji bagaimana kebijakan pemukiman bagi Suku Laut di Bertam berdampak pada kehidupan mereka melalui skema yang ia usulkan (Rahmawati, 2014). Skema tersebut dibagi menjadi beberapa segi, diantaranya: dampak budaya, dampak lingkungan, dampak sosial dan politik, dampak ekonomi, dan dampak personal-spiritual. Selain itu 
Prawisusanto $(2014,2015)$ juga mengkaji program pemukiman untuk Orang Laut di Pulau Bertam melalui kerangka govermentality dan infrastruktur. Menurutnya, gagalnya program pemukiman bagi Suku Laut adalah akibat dari kurang mapannya pemerintah dalam melakukan pendampingan. Melalui data etnografisnya yang dalam, penulis memperlihatkan aspek kultural seperti kekerabatan yang lebih menentukan relasi Suku Laut dengan infrastruktur yang diberikan oleh pemerintah. Pola pemukiman Orang Laut di Pulau Bertam yang kian 'melenceng' dari model yang sudah ditentukan dalam perencanaan pemerintah, ternyata sangat ditentukan oleh aspek kebudayaan Suku Laut yang cenderung tinggal berkelompok berdasarkan hubungan kekerabatan yang terdekat (Prawirosusanto, 2015).

Beberapa kajian di atas menempatkan Orang Laut sebagai masyarakat yang hidup dalam satu ruang lingkup negara. Padahal pada kenyataannya Orang Laut di Kepulauan Riau hidup dalam ruang perbatasan antar tiga negara yaitu Indonesia, Singapura, dan Johor (Malaysia). Hal ini yang membuat saya tertarik untuk mengkaji Suku Laut di Kepulauan Riau yang hidup dalam realitas landscape yang berlapis. Realitas itu di antaranya dimiliki oleh negara, pasar, dan realitas milik mereka sendiri sebagai komunitas yang hidup di dalamnya (Chou, 2005).

Sehingga tidak hanya melihat intervensi negara dalam melihat proses sedentarisasi dan perubahan livelihood di masyarakat Suku Laut. Terdapat skala yang lebih luas, yaitu transnasional, di mana perubahan relasi pasar atau komoditas yang juga ikut mempengaruhi perubahan pola hidup Suku Laut. Menempatkan Suku Laut dalam konteks perbatasan, berarti melihat entitasnya yang hidup berada di antara dua sistem yang saling berkontestasi, yaitu sistem pasar dan negara (Lumenta, 2011). Salah satu penelitian yang menitikberatkan pengaruh kondisi pasar terhadap proses sedentarisasi dan perubahan pola hidup masyarakat, adalah tulisan Kazufumi Nagatsu (1994) tentang Orang Bajau (Ishikawa, 2008). Nagatsu berpendapat bahwa faktor-faktor yang mendorong sedentarisasi Orang Bajau adalah penetrasi ekonomi pasar, munculnya produk maritim yang baru berupa rumput laut, dan inovasi teknologi alat tangkap. Faktor-faktor tersebut secara berkaitan mendorong Orang Bajau untuk hidup lebih berorientasi kepada daratan. Hal itu pula yang menyebabkan terjadinya berbagai perubahan sosial seperti ditinggalkannya pola hidup nomaden dan semakin jelasnya pola pemukiman yang terkonsentrasi di antara komunitas Bajau, diferensisasi si kaya dan si miskin, penerimaan terhadap agama Islam dan Kristen, dan semakin beragamnya mata pencaharian.

Dalam kasus Suku Laut di Kepulauan Riau, proses sedentarisasi tidak sepenuhnya menghentikan mereka dari kegiatan nomaden. Dalam waktu tertentu Suku Laut pergi kerja melaut dan meninggalkan rumah mereka yang berada di pinggiran daratan seminggu hingga berbulan-bulan lamanya. Sehingga saya juga tidak dapat mengabaikan bahwa di tengah-tengah dua sistem (negara dan pasar) yang berpengaruh dalam proses sedentarisasi dan perubahan livelihood, Suku Laut masih mencoba mempertahankan ketergantungannya terhadap laut sambil berusaha untuk mencari ruang penghidupan lain.

\section{Berada di antara Seascape dan Landscape}

Suku Laut kini memiliki rumah. Rumah seringkali menjadi metafora sebagai 'tempat beristirahat', 'tempat kembali' atau 'berpulang'. Sehingga rumah dapat dilihat sebagai place, yaitu sesuatu yang melekat dan menubuh pada konteks lokal tertentu. Sedangkan jika merujuk pada paparan Lowe (2003:23) mengenai space adalah produk dari perpindahan/pergerakan dan refleksifitas, maka daratan juga merupakan space bagi Suku Laut yang kini tidak hanya melakukan mobilitas di laut tetapi juga di darat. Hal itu digambarkan secara jelas oleh Prawisusanto (2015), mengenai Suku Laut yang 'mendarat' atau memiliki kesadaran baru sebagai orang darat. Munculnya istilah 'kerja darat' sebagai penanda dari kesadaran yang mendarat tersebut. Dalam paparannya itu, kesadaran Suku Laut yang mendarat seolah-olah adalah hal yang baru dalam kehidupan Suku Laut yang terkenal sebagai sea nomad, yang kehidupannya hanya berorientasi pada laut (Prawirosusanto, 2015). 
Saya katakan 'seolah-olah baru' karena dalam tulisan lain mengenai tenurial and territoriality Suku Laut yang dipaparkan dalam "Contesting the Tenure of Territoriality: The Suku Laut", secara implisit menunjukkan bahwa Suku Laut juga sebenarnya mengidentifikasi darat sebagai wilayah produksi (Chou, 1997). Daratan juga tidak lepas dari identifikasi Suku Laut, walaupun hanya sebagai lokasi untuk menguburkan saudaranya. Oleh karena itu, asumsi tentang kebaruan Suku Laut yang mendarat harus kita refleksikan secara hati-hati (Lenhart, 2001).

Tulisan lain mengenai space muncul dalam artikelnya yang berjudul "The Water World of the Suku Laut in Southeast Asia". Tulisannya itu membahas maritime scape atau juga seascape, untuk menjelaskan relasi Suku Laut dengan lingkungannya. Bahwa sama halnya dengan ruang daratan yang embodied, seascape merupakan produk dari suatu proses belajar merujuk pada istilah Ingold (2000) yaitu "sensory education" melalui aktivitas learning by living yang melibatkan sensitivitas dan pengalaman (Chou, 2016).

Melalui "The magic of place: Sama at sea and on land in Sulawesi, Indonesia", menjelaskan secara eksplisit dua orientasi Orang Bajau yang tidak dapat dipisahkan. Jika Chou (2016) melihat sense of space dunia maritim Suku Laut melalui siklus kehidupan, maka dalam tulisan ini Lowe mengangkat sense of place dan persepsi mengenai teriorial Orang Bajau. Konsekuensi dari perbedaan tersebut adalah Laut sebagai medium dapat diposisikan berbeda. Sebagai sense of place, laut adalah ruang atau wilayah kecil tempat Orang Bajau hidup dan mencari penghidupan. Sedangkan sebagai sense of space, laut adalah ruang jelajah yang harus ditelusuri dan dipelajari. Pengetahuan yang ada bukanlah pengetahuan yang mengendap dan statis, melainkan ia didapat melalui 'revelation'(Lowe, 2003).

Sedikit berbeda dengan para penulis sebelumnya yang menekankan pada faktor keagensian laut sebagai medium yang membentuk perspektif ruang Suku Laut, ide Suku Laut tentang ruang dan tempat justru lebih banyak menekankan aspek sosial. Menurutnya perspektif ruang dan teritori Suku Laut didasarkan pada prinsip atau sense of otherness. Ruang dipandang sebagai sekat-sekat yang memisahkan antara Suku Laut dengan dunia luar. Pada dasarnya Suku Laut membangun rasa aman berdasarkan 'social intimacy'. Bagi mereka 'tempat' bukan berarti locus, melainkan suatu ruang yang memberikan rasa aman, dan ruang itu adalah lingkar kerabat terdekat dengan sosok tetua sebagai pemimpin (Lenhart, 2008).

Kini pertanyaannya adalah bagaimana konsekuensi dari sendentarisasi terhadap cara Suku Laut memandang realitas ruang dan tempat yang mereka tinggali? Baik laut ataupun darat, pada dasarnya adalah satu dan merupakan alam kebudayaan mereka. Hal itu telah tertanam dalam prinsip primordial mereka sebagai orang pertama yang menghuni alam melayu (Lenhart, 2008). Namun kini zaman telah berubah, berbagai upaya dilakukan untuk membawa Suku Laut untuk berasimilasi dengan komunitas lain yang juga tinggal di tanah melayu, yaitu dengan sedentarisasi (Lenhart, 2001). Dengan bermukim maka kemungkinan Suku Laut untuk berinteraksi dengan komunitas lain semakin meningkat, dan meningkatkan resiko konflik interetnik. Bermukim juga menempatkan Suku Laut dalam situasi yang harus berkonfrontasi dengan nilai-nilai baru, memberikan tekanan kepada Suku Laut untuk berasimilasi dengan masyarakat umum dan meningkatkan ethnic self-awareness dalam diri mereka (Lenhart, 1997).

Sedentarisasi juga tampaknya memberikan batasan yang sangat jelas antara darat dan laut. Daratan menjadi semakin asing yang menjadi tempat masyarakat pada umumnya bermukim, sekaligus juga harus semakin diakrabi karena transaksi ekonomi dan kegiatan kemasyarakatan lebih banyak dilakukan di darat. Begitupun dalam hal mencari penghidupan, terjadi diversifikasi pekerjaan yang mengandalkan sumber daya di darat melalui mekanisme kerja darat (Prawirosusanto, 2014). Kemudian menurutnya, kehadiran rumah memberikan kemungkinan-kemungkinan akan adanya ruang ketiga, yaitu sebuah ruang 'antara' yang menengahi darat dan laut. Ruang antara juga merupakan ruang transisi, menunjukan tempat di mana perubahan itu sebenarnya terjadi. Dengan mulai tinggal di rumah, maka suku laut mulai 
meninggalkan kebiasaan berpindah-pindah (mobile) yang mana hal itu merupakan spatial behavior ketika mereka masih hidup di sampan (Lenhart, 2008). Tentunya perubahan spatial behavior tersebut berpengaruh terhadap aspek lainnya seperti livelihood, organisasi sosial, dan relasi gender.

Hemat saya, orientasi darat dan laut Suku Laut tidak pernah berubah. Tidak berubah dalam artian kedua lokus tersebut selalu penting dalam kehidupan Suku laut, hanya saja ada yang berubah dalam sense of place, pengalaman, dan ikatan mereka dengan dua lokasi tersebut. Sehingga yang terlihat adalah Suku Laut berdiri di atas dua pijakan - seascape dan landscape - yang saling tarik menarik. Kedua lokus tersebut memang selalu menjadi ruang jelajah yang tak lepas dari arena mobilitas Suku Laut. Baik seascape atau pun landscape, selalu menjadi sumber pengetahuan dan sumber penghidupan, keduanya menjadi ruang belajar yang membentuk persepsi Suku Laut mengenai ruang yang mereka huni. Adapun yang harus lebih banyak ditinjau adalah hadirnya ruang ketiga, yaitu ruang antara yang kini hadir dalam bentuk rumah semi-daratan yang menghubungkan realitas darat dan laut, sekaligus mengantarkan Suku Laut kepada sekat-sekat baru, salah satunya yang memisahkan aktifitas laki-laki dan perempuan.

\section{Space dan Gender}

Dari beberapa pustaka yang telah dipaparkan, gender Suku Laut belum banyak dipaparkan oleh peneliti sebelumnya. Tampaknya penelitian terdahulu masih belum banyak yang secara khusus mengeksplorasi ruang perempuan ataupun dimensi gender di suku laut. Padahal Lenhart (1995) dalam sebuah artikel yang ia tulis, menyebutkan bahwa isu-isu mengenai gender (khususnya perihal pembagian peran) menjadi isu yang masih perlu didalami. Adapun saya temukan naskah akademik sebelumnya yang menaruh perhatian pada bahasan mengenai gender ditulis oleh Lenhart (2003) dan Chou (2006). Meskipun berbeda dalam hal pembahasan dan format penulisan, keduanya memperlihatkan bagaimana proses modernisasi dan pembangunan telah membawa dinamika dalam memaknai perbedaan antara laki-laki dan perempuan di Suku Laut.

Lenhart dalam "Encyclopedia of Sex and gender" (2003), menulis salah satu bagian yang secara khusus membahas gender dan seks Suku Laut. Ia menulis secara rinci pembahasan mengenai seks dan gender, yang dibagi menjadi beberapa sub-bahasan yang saling berkaitan. Pembahasan diawali dengan deskripsi secara umum mengenai Suku Laut di Kepulauan Riau dan konstruksi gender secara kultural yang terjadi di Suku Laut. Menurutnya walaupun seks di Suku Laut dibedakan secara jelas secara biologis antara laki-laki dan perempuan, namun dalam realitas sosialnya menunjukan hal yang lain. Apa yang di masyarakat umum secara ideal diasosiasikan sebagai 'laki-laki' ataupun juga 'perempuan', hal itu tidak terlalu terlihat di Suku Laut. Oleh karena dalam kesehariannya laki-laki juga ikut bersolek, seperti memerahkan bibir, menggambar alis, atau menggunakan asesoris-asesoris lain yang biasanya sering diasosiasikan sebagai atribut perempuan. Laki-laki juga bisa memasak dan mengurus anak, begitupun perempuan yang bisa pergi mancing dan ikut bekelam (pergi mencari ikan dalam waktu yang lama, bisa berhari-hari hingga berminggu-minggu). Pada dasarnya Orang Laut tidak secara tegas mengarahkan individu untuk menjadi laki-laki ataupun juga perempuan, karena masingmasing dilihat dari apa yang Lenhart katakan sebagai 'individual performance' (Lenhart, 2003).

Kemudian, membahas gender dalam siklus hidup Suku Laut yang dimulai dari bahasan mengenai sosialisasi kepada anak perempuan maupun anak laki-laki. Umumnya di komunitas Suku Laut, agen sosialisasi bisa jadi ayah ataupun ibu. Selain itu saudara yang lebih besar, orang-orang tua, dan orang yang menjadi bagian dalam kelompok bersampan juga menjadi agen sosialisasi. Hal itu menunjukan bahwa lingkar kerabat terdekat yang membentuk individu dalam kehidupan sehari-hari, agen sosialisasi bisa dilakukan oleh perempuan dan laki-laki, 
menunjukan bahwa struktur sosial Suku Laut memang tidak berorientasi kepada perempuan ataupun laki-laki.

Pernikahan idealnya dilakukan secara endogami, hal itu memang lebih efisien dalam mempertahankan keamanan kelompok. Pernikahan endogami juga menjaga individu agar tetap berkelompok ketika berpergian, ataupun juga ketika membangun sebuah kampung. Pasangan baru, biasanya tinggal terlebih dahulu di keluarga perempuan dan sesekali tinggal di keluarga laki-laki. Namun tidak menutup kemungkinan untuk terjadi hal yang sebaliknya. Peran istri maupun suami dalam perekonomian keluarga sifatnya saling melengkapi dan saling mendukung (komplementer). Jika suami biasanya bertugas sebagai penombak, maka sang istri bertugas sebagai pendayung. Keduanya memiliki peran yang sama-sama penting untuk memenuhi kecukupan subsistensi keluarga. Begitupun dengan kerja domestik, seperti membersihkan sampan atau juga rumah, memasak dan mengurus anak, dilakukan bersamasama.

Kepemimpinan di Suku Laut umumnya terdapat satu sosok pemimpin dalam satu kelompok, sosok pemimpin ini biasanya orang yang dituakan dan seringkali laki-laki. Akan tetapi meskipun yang menjadi pemimpin adalah laki-laki, biasanya pasangannya (istrinya) memiliki pengaruh pada posisi tersebut. Ketika terjadi pertemuan misalnya, suara atau pendapat dari pasangan tetua juga selalu didengarkan dan menjadi bahan pertimbangan. Selain itu, terdapat posisi penting lainnya yang juga penting yaitu pemimpin politis seperti ketua RT setempat, bomoh atau dukun (bisa laki-laki juga perempuan), ketua batin (seringkali laki-laki), tetua perempuan, pembuat sampan (laki-laki), dan bidan (perempuan). Secara garis besar, baik laki-laki atau juga perempuan dapat menyuarakan pendapatnya karena relasi gender di Suku Laut lebih bersifat egaliter. Komunikasi dalam sehari-hari sifatnya permisif, tidak ada ruang yang secara eksklusif diperuntukan hanya untuk laki-laki ataupun perempuan.

Kesadaran akan perbedaan seks secara biologis, dengan relasi gender yang sifatnya lebih kepada egaliter dan permisif tersebut nyatanya patut direfleksikan ulang. Terlebih ketika Suku Laut mulai diakui sebagai bagian dari sistem yang hari ini kita sebut sebagai negara, maka ada banyak intervensi dalam mengatur cara hidup Suku Laut yaitu dengan diterapkannya cara hidup bermukim. Chou (2006) dalam tulisannya, tentang realitas berlapis di perbatasan yang juga menjadi lokasi Suku Laut, ia melihat adanya pemberlakuan sistem gender - atau dalam istilah yang digunakan Chou adalah gendering border - sebagai implikasi dari dua sistem yang berlaku di perbatasan (Chou, 2005). Menurut Chou, dalam proses pemberlakuan dua sistem (negara dan pasar), berlaku juga suatu proses penciptaan makna atas makna-makna yang telah ada, atau yang diistilahkannya sebagai meaning making dan meaning breaking. Menurutnya negara merupakan agensi yang dapat menciptakan makna, dan Suku Laut adalah orang-orang yang harus mengikutinya. Kemudian Chou pun menjelaskan bahwa sistem gender yang diberlakukan oleh negara itu muncul menjadi bagian dari agenda sedentarisasi Suku Laut melalui penerapan gaya hidup bermukim, yang mengatur ruang berdasarkan jenis kelamin lakilaki dan perempuan.

Hal serupa juga dipaparkan oleh Lenhart (2003) di bagian akhir deskripsinya mengenai relasi gender Suku Laut, menurutnya perubahan-perubahan tersebut merupakan keniscayaan, terutama bagi Suku Laut yang sudah bermukim dan mulai meninggalkan cara hidup nomaden. Ketika mereka mulai menetap maka peluang untuk terjadinya kontak antar-etnis semakin besar, hal itu ditambah dengan tekanan untuk merubah gaya hidup dan berasimilasi dengan masyarakat pada umumnya dari pemerintah melalui program-programnya (Lenhart, 2003). Perubahan tersebut memperlihatkan meningkatnya dominasi laki-laki di lokasi pemukiman, salah satu indikatornya adalah lemahnya keterlibatan perempuan setiap kali ada pertemuan atau kunjungan dari aparat pemerintah. Perubahan perilaku tersebut didorong oleh para aparat yang biasanya hanya melihat laki-laki Suku Laut sebagai pihak yang kompeten dan mudah didekati, 
ketika pertemuan berlangsung biasanya mereka mengatur letak duduk dan memisahkan lakilaki dan perempuan (Lenhart, 2003).

Selain itu, proses sendentarisasi yang terjadi secara terus-menerus juga telah membawa perkembangan dalam hal pembagian peran gender. Perempuan Suku Laut yang pada awalnya juga ikut pergi melaut, kini mulai menempatkan dirinya secara ekslusif pada kerja-kerja domestik (Lenhart, 2003). Pada akhirnya, berkembangnya pembagian kerja berdasarkan seks juga berpengaruh terhadap ekspektasi kepada anak-anak, membawa Suku Laut untuk meredefinisikan apa itu laki-laki atau perempuan di komunitasnya. Itu semua merupakan nilainilai baru dalam proses modernisasi yang harus diterima demi mendorong asimilasi Suku Laut dengan masyarakat pada umumnya.

Sama seperti Lenhart, Chou juga berasumsi bahwa proses sedentarisasi mempengaruhi relasi gender, baik dalam tingkat individu hingga komunitas lokal (Chou, 2016). Perempuan Suku Laut menjadi 'didomestikan' dengan diberlakukannya nilai-nilai baru dalam bermukim. Tentunya hal itu juga menyebabkan terjadi pembatasan ruang perempuan yang pada awalnya dapat melaut, kini mereka memiliki kewajiban terhadap tugas-tugas domestik. Gambaran yang nyata dipaparkan mengenai program puskesmas terapung, walaupun perspektif yang digunakan adalah perspektif perancang program. Dalam gambaran tersebut perempuan Suku Laut ditampilkan sebagai kelompok yang masih perlu diedukasi dengan nilai-nilai modern. Menurutnya perempuan Suku Laut masih belum mengerti mengenai tugasnya sebagai ibu rumah tangga yang memiliki kewajiban dalam memelihara sandang - pangan - papan keluarga, praktisnya perempuan Suku Laut juga belum mengerti benar perihal kesehatan, padahal hal itu merupakan bagian dari tugas seorang ibu rumah tangga. Nilai-nilai seperti itu yang ingin pemerintah terapkan dalam kehidupan Suku Laut.

Berbagai deskripsi sebelumnya, yang menunjukan dinamika relasi dan peran gender dalam komunitas Suku Laut sebagai konsekuensi dari proses sedentarisasi, akan lebih menarik jika dilihat dalam kerangka gendered space. Definisi dari gendered space sendiri dapat dipahami sebagai: (1) suatu lokus yang disematkan makna-makna berbasis gender oleh kebudayaan di dalamnya; (2) sebagai lokasi di mana praktik-praktik atas perbedaan seks terjadi; dan (3) dipahami sebagai situasi yang secara strategis digunakan untuk memproduksi dan mereproduksi relasi gender yang tidak setara (Lowe, 2003). Ketiga definisi tersebut memperlihatkan bagaimana gendered space sendiri dapat dilihat dalam berbagai level analisis. Untuk definisi yang pertama mungkin tidak banyak muncul dalam kebudayaan Suku Laut yang pada dasarnya lebih menilai individual performance (Lenhart, 2003). Sedangkan definisi yang kedua dan ketiga dapat dilihat dari proses sedentarisasi yang sedang berlangsung, di mana kehadiran rumah sebagai realitas ruang dan tempat yang baru telah memantik artikulasi peranan dan relasi gender dalam keseharian Suku Laut. Seperti halnya pendapat Low dan Zúñiga (2003), bahwa rumah seringkali dilihat sebagai gendered space, karena perannya sebagai lokus dari aktifitas produksi dan reproduksi yang memungkinkan terjadinya artikulasi spasial dari peran perempuan. Pendapat tersebut semakin menegaskan gagasan Rosaldo (1974) yang melihat keterkaitan subordinasi perempuan dalam hubungannya dengan domestic sphere. Perbedaan yang mendasar antara kedua pandangan tersebut dengan kasus Suku Laut, ada pada asumsi bahwa rumah merupakan realita baru bagi Suku Laut sebagai komunitas yang sebelumnya menjalani kehidupan nomaden. Sehingga nilai-nilai yang menentukan posisi dan peranan perempuan dalam aktifitas domestik, merupakan bagian dari dinamika perubahan sosial dan budaya komunitas ini.

\section{Simpulan}

Suku Laut sebagai komunitas nomaden, memiliki kebudayaan yang sangat erat dengan laut sebagai lingkungan yang juga menjadi orientasi dari alam kebudayaan - kosmologi mereka. Hal itu tercermin dalam kebiasaan dan aktifitas sehari-hari mereka dalam upaya 
mencari penghidupan yang sebagian besar bersumber dari laut. Dalam menunjang aktifitas tersebut, Suku Laut mengandalkan teknologi dan pengetahuan yang didapatkan dari warisan nenek moyang dan pengalaman hidup, didukung dengan sistem pengorganisasian yang bergantung pada tindakan dan keahlian setiap individu. Sayangnya, gaya hidup berbasis mobilitas tersebut dipandang lain oleh negara. Kebiasaan berpindah tempat Suku Laut dipandang seperti masyarakat yang 'liar', tidak dapat diatur, sehingga perlu diberlakukan suatu mekanisme pendisiplinan. Melalui program pemukiman, komunitas ini ditertibkan agar dapat dicatat secara administrasi, dan dapat dipantau pergerakannya. Dinamika pasar juga nyatanya turut membentuk nilai-nilai baru dalam komunitas ini, yang mendorong mereka untuk memiliki hasrat material yang merupakan ciri khas masyarakat dengan gaya hidup menetap.

Perlahan-lahan komunitas ini mengalami perubahan, terutama dalam segi spasialitas. Hal yang paling terlihat adalah berkurangnya jangkauan untuk melakukan mobilitas. Laut yang dulu sangat luas untuk dijelajahi, kini tampak semakin sempit karena Suku Laut mulai terikat dengan pemukiman sebagai ruang hidup. Rumah sebagai ruang antara, menjembatani realita antara darat dan laut, yang sebelumnya merupakan sebuah kesatuan dalam alam kebudayaan Suku Laut sebagai komunitas Melayu tertua di Kepulauan Riau. Selain itu, rumah juga menjadi lokus untuk terjadinya artikulasi dalam mendefinisikan ulang relasi dan peran gender Suku Laut. Kehadiran ruang domestik, memberi definisi baru akan peranan dan posisi perempuan Suku Laut. Meski dalam tatanan ideal menunjukan relasi laki-laki dan perempuan yang bersifat egaliter, nyatanya perempuan banyak diatur oleh nilai-nilai baru yang bersumber dari interaksi dengan berbagai pihak dari luar komunitas yang memiliki kepentingan dalam memukimkan Suku Laut.

Oleh karena itu, perlu adanya kajian lebih lanjut untuk melihat dinamika yang terjadi dalam keseharian Suku Laut. Dilihat dari sedikitnya literatur mengenai Suku Laut di Kepulauan Riau, belum banyak akademisi dan aktifis yang mengenal dan tertarik untuk mengkaji dan melakukan kerja-kerja advokasi untuk komunitas ini. Kerja advokasi diperlukan agar komunitas ini dapat berpijak pada nilai dan kearifan lokal yang mereka miliki, sehingga mereka dapat berstrategi dalam menegosiasikan kepentingan mereka di arena yang lebih luas. Gambaran mengenai kebudayaan dan problematika Suku Laut dalam tulisan ini, baiknya ditindaklanjuti menjadi suatu kajian yang lebih mendalam, terutama untuk lebih dalam meninjau aspek gender Suku Laut yang kini sedang mengalami perubahan. Perempuan Suku Laut yang mulai terikat dengan kerja-kerja domestik kini mulai berjarak dengan laut yang selama ini menjadi arena mereka dalam mengaktualisasikan keterampilan dan pengetahuannya sebagai perempuan Suku Laut. Oleh karena itu diperlukan kajian empiris dan mendalam mengenai hal itu.

\section{Rujukan}

Benjamin, G., \& Chou, C. (n.d.). Tribal communities in the Malay World: Historical, cultural and social perspectives. Kuala Lumpur: Institute of Southeast Asian Studies.

Chou, C. (1997). Contesting the Tenure of Territoriality: The Suku Laut. Bijdragen Tot De Taal-, Land- En Volkenkunde, 153(4), 605-629.

Chou, C. (2005). Indonesian sea nomads: money, magic and fear of the Suku Laut. Routledge.

Chou, C. (2016). The Water World of the Suku Laut in Southeast Asia. TRaNS: Trans Regional and-National Studies of Southeast Asia, 4(2), 265-282.

Ishikawa, N. (2008). Centering Peripheries: Flows and Interfaces in Southeast Asia. Kyoto: Kyoto University.

Kent, S. (1995). Does Sedentarization Promote Gender Inequality? A Case Study from the Kalahari. The Journal of the Royal Anthropological Institute, 1(3), 513-536. 
Lenhart, L. (1997). Suku Laut ethnicity and acculturation. Bijdragen tot de Taal-, Land-en Volkenkunde, 4(1), 577-604.

Lenhart, L. (2001). Suku Laut Communities At Risk: Effects Of Modernisation On The Resource Base, Livelihood And Culture Of The "Sea Tribe People" Of The Riau Islands (Indonesia). Nomadic Peoples, 5(2), 67-88.

Lenhart, L. (2003). Suku Laut. Encyclopedia of Sex and Gender: Men and Women in the World's Culture. New York: Springer Science \& Business Media.

Lenhart, L. (2008). Sea nomads' mobile dwellings and settlements and their ideas of place and space. Indonesian Houses, 1(1), 309-341.

Lenhart, L., \& Casimir, M. (2001). Environment, Property Resources And The State: An Introduction. Nomadic Peoples, 5(2), 6-20.

Lowe, C. (2003). The magic of place: Sama at sea and on land in Sulawesi, Indonesia. Bijdragen Tot De Taal-, Land-En Volkenkunde, 159(1), 109-133.

Lumenta, D. (2011). Moving in a Hierarchized Landscape: Changing Border Regimes in Central Kalimantan. Wacana, 13(1), 121-145.

Prawirosusanto, K. . (2014). Suku Laut dan Orang Melayu di Kepulauan Riau: sebuah tafsir deskriptif-etnografis. Antropologi Indonesia, 31(3), 224-239.

Prawirosusanto, K. . (2015). Orang Laut, Pemukiman, dan Kekerasan Struktur. Masyarakat Indonesia, 41(2), 14-28.

Rahmawati, A. (2014). Kehidupan Suku Laut di Batam: Sebuah Fenomena Kebijakan Pembangunan di Pulau Bertam, Kota Batam. Share Social Work Journal, 4(1), 12-24.

Wee, V., \& Chou, C. (1997). Continuity and discontinuity in the multiple realities of Riau. Bijdragen tot de Taal-, Land-en Volkenkunde, 4(1), 527-541. 